\title{
AshNet: Facilitating the use of wood ash as a forest soil amendment in Canada
}

\author{
by K.D. Hannam", ${ }^{1,}$ L. Venier ${ }^{1}$, E. Hope ${ }^{1}$, D. McKenney ${ }^{1}$, D. Allen ${ }^{1}$ and P.W. Hazlett ${ }^{1}$
}

\begin{abstract}
The growing demand for bioenergy has raised concerns about the sustainability of intensive forest biomass removal. Less attention has been paid to the ash generated when forest biomass is combusted to produce energy. In Canada, this ash is often landfilled, but in some countries, wood ash is applied to the soil to maintain or improve soil fertility and forest health. AshNet is a network of Canadian scientists, foresters, policy makers and industry representatives that has formed to address opportunities for and challenges to the use of wood ash as a forest soil amendment. To date, AshNet collaborators have produced a guide to navigating the regulatory approval process, and completed a techno-economic analysis of the costs associated with landfilling wood ash versus using it as a forest soil amendment. Practical methods for optimizing ash quality and applying it on forested sites are being investigated. Applications of wood ash are also being examined as a tool for emulating some of the effects of wildfire on soil chemistry. The results of research trials established by AshNet collaborators across Canada will be shared to help develop and refine forest management policies and practices surrounding soil applications of wood ash. Updates on AshNet's activities are available at (http://cfs.nrcan.gc.ca/projects/140 (English); http://scf.rncan.gc.ca/projets/140?lang=fr_CA (French)).
\end{abstract}

Keywords: bioenergy, wood ash, forest soil, forest biomass, biomass harvesting, acid rain, emulation of natural disturbance

\section{RÉSUMÉ}

La demande croissante pour la production de bioénergie a soulevé des inquiétudes quant à la durabilité de la récolte intensive de biomasse forestière. On sest toutefois moins préoccupé des cendres produites par la combustion de la biomasse forestière pour la production dénergie. Au Canada, ces cendres sont souvent enfouies, tandis que dans certains pays, la cendre de bois est répandue sur le sol pour maintenir ou améliorer sa fertilité et la santé des forêts. AshNet est un réseau canadien de chercheurs, de forestiers, de décideurs politiques et de représentants de l'industrie qui a été mis sur pied pour se pencher sur les possibilités et les défis liés à l'utilisation des cendres de bois pour amender les sols forestiers. À ce jour, les collaborateurs d'AshNet ont produit un guide pour mieux comprendre le processus réglementaire d'approbation en plus de réaliser une analyse techno-économique des coûts associés à lacheminement des cendres de bois dans une décharge par rapport à leur utilisation pour l'amendement des sols forestiers. On explore présentement les méthodes pratiques pour optimiser de la qualité des cendres et les épandre sur les sites forestiers. On s’intéresse également à mieux connaître comment lépandage des cendres de bois pourrait reproduire certains des effets des feux de forêt sur la chimie du sol. Les collaborateurs du réseau AshNet entendre partager les résultats des essais qu'ils ont établis au Canada afin de contribuer au développement et à lamélioration des politiques et des pratiques d’aménagement forestier liées à lépandage des cendres de bois. On peut consulter les rapports sur les activités d’AshNet à (http://cfs.nrcan.gc.ca/projects/140 (anglais); http://scf.rncan.gc.ca/projets/140?lang=fr_CA (français)).

Mots clés : bioénergie, cendre de bois, sol forestier, biomasse forestière, récolte de la biomasse, pluies acides, émulation d'une perturbation naturelle

\section{Introduction}

Efforts to mitigate greenhouse gas emissions depend on replacing fossil fuel-based energy production with that from renewable sources. Canada is already the fourth largest producer of renewable energy in the world but most is generated at hydro-electric dam facilities (National Energy Board of Canada 2016). That being said, the forest industry has a long history of producing heat and power by burning timber and pulp and paper processing residues (Griffin and Nyboer 2016). Increasingly, other sources of forest biomass are being considered as possible sources of energy (Paré et al. 2016). These include: (i) the tree branches and tops, cull logs, and unmerchantable stems that are typically piled at the roadside and burned or left within the stand to decay after logging; (ii) wood salvaged after insect outbreaks or wildfire; and, (iii) dead woody material generated during stand break-up and self-thinning (Ontario Ministry of Natural Resources 2008, Dymond et al. 2010, Roach and Berch 2014). The prospect of industrial-scale forest biomass harvesting has raised concerns about possible negative impacts on forest biodiversity, habitat

\footnotetext{
${ }^{1}$ Natural Resources Canada, Canadian Forest Service, Great Lakes Forestry Centre, Sault Ste. Marie, Ontario P6A 2E5; corresponding author: kirsten.hannam@canada.ca
} 
quality, site productivity, soil nutrient cycling and hydrology (e.g., Lattimore et al. 2009, Thiffault et al. 2011, Roach and Berch 2014). To date however, less attention has been paid to the growing volume of wood ash generated as a by-product of bioenergy production.

Wood ash is often treated as a waste material in Canada and landfilled. However, this situation is changing: in 1995, $84 \%$ of the ash produced in power and recovery boilers at pulp and paper mills was landfilled; by $2002,78 \%$ of this was landfilled and in 2013, only 63\% was landfilled (Elliott and Mahmood 2006, Elliott and Mahmood 2015). Nevertheless, wood ash disposal rates vary considerably among provinces. In Québec, about 50\% of approximately $300000 \mathrm{Mg}$ of wood ash produced in 2005 was landfilled (Hébert and Breton 2009) and in Alberta, some $51 \%$ of approximately $60000 \mathrm{Mg}$ of wood ash produced in 2015 was landfilled (G. Dinwoodie, Land Reclamation Specialist - Alberta Environment and Parks, Land Policy Branch, personal communication, September 2016). By contrast, some $96 \%$ of about $235000 \mathrm{Mg}$ of wood ash produced in British Columbia in 2014 was landfilled (Nishio 2016).

When wood ash is diverted from landfills, it has a wide range of beneficial uses e.g., as a liming agent and fertilizer on agricultural soils, as capping material at landfills, as road aggregate, as fill material in building construction, in concrete manufacturing, and as an odour absorbent (Elliott and Mahmood 2006). Numerous studies have demonstrated that applications of wood ash on forest soils can be used to replace some of the nutrients, e.g., phosphorus (P), calcium (Ca), magnesium $(\mathrm{Mg})$, potassium $(\mathrm{K})$ removed during timber harvesting; counteract the effects of acid rain on forest soils and surface water bodies; and, improve tree growth (Pitman 2006, Huotari et al. 2015, Reid and Watmough 2015). In some European countries, applications of wood ash are encouraged to prevent nutrient deficiencies following biomass harvesting, particularly on nutrient-poor forest sites (Karltun et al. 2008, Forestry Commission 2009). Therefore, the disposal of wood ash in Canadian landfills potentially represents a wasted opportunity to obtain greater value from forest biomass while enhancing the ecological sustainability of forestry operations.

There are a number of questions and concerns that must be addressed before the use of wood ash as a forest soil amendment becomes common across Canada. AshNet, a network of scientists, foresters, industry and government representatives, has been created with the goal of reducing waste and improving the sustainability of forest management by encouraging the use of wood ash as a potential soil amendment. AshNet has produced a dedicated website to house scientific, technological, regulatory and economic information about wood ash applications on forest soils in Canada: http://cfs.nrcan.gc.ca/projects/140 (English); http://scf.rncan. gc.ca/projets/140?lang=fr_CA (French). The website will be updated as new information becomes available. Below we describe some of the steps that AshNet and its collaborators are taking to address the most pressing barriers to the use of wood ash as a forest soil amendment.

\section{Navigating the regulatory process}

In many provinces, there is a perceived lack of clarity surrounding the process for obtaining regulatory approval to use wood ash as a soil amendment. To address this gap, AshNet has compiled information on the regulatory approval process for each province and territory in Canada (Hannam et al. 2016). This information has been published and is available for download from the AshNet web page.

\section{Developing protocols for handling and applying wood ash}

Wood ash is caustic and the dust produced during handling can be a significant safety hazard. For obvious reasons, applying wood ash on forested sites can present greater technical challenges than applying ash on bare agricultural fields. Work has been conducted in Québec by FPInnovations in collaboration with Domtar Corporation to evaluate the use of agricultural spreaders, mounted on a standard forwarder, for applying wood ash (or mixtures of wood ash and biosolids) on forested sites (Nishio and Ersson 2016a, 2016b).

\section{Improving wood ash quality}

To our knowledge no guidance has been developed to strategically manipulate the quality of Canadian wood ash. However, wood ash chemistry can be optimized via careful control of feedstock quality, combustion temperature and airflow, and collection of ash into separate bottom and fly ash fractions (Elliott and Mahmood 2006). The term 'bottom ash' refers to the slag-like material collected from the base of a combustion system, while 'fly ash' refers to the fine particles scrubbed from the flue gas before it enters the atmosphere. Because of its higher surface-to-volume ratio, fly ash is more chemically reactive than bottom ash. As well, fly ash can become enriched in trace metals during the processes of biomass combustion and cooling. Stockpiling and mixing different batches or types of ash with known chemical compositions can be used to ensure that the ash actually applied to the soil contains optimal concentrations of nutrients and trace metals (Elliott and Mahmood 2006). AshNet collaborators at the University of Northern British Columbia (UNBC) are currently investigating this approach using stockpiled wood ash (bottom and fly) produced in UNBC's bioenergy plant (M. Rutherford, Professor - Environmental Science \& Engineering, UNBC, personal communication, August 2016). In the meantime, data on the chemistry of bottom and fly ash produced across Canada from a range of feedstocks and boiler types have been compiled and will be made publically available on the AshNet website. This information will be useful for demonstrating how widely the chemistry of wood ash can vary and, we hope, stimulate discussion about methods for improving ash quality in order to maximize its economic value.

\section{Addressing techno-economic barriers}

A recent techno-economic analysis conducted by AshNet researchers at Natural Resources Canada (NRCan) suggests that the application of wood ash on forest soils can be an economical method of ash disposal available to producers. This depends on factors such as landfilling costs, distance to forest sites, and spreading costs, which can vary with local regulations and ash preparation costs (Hope et al. submitted). Accounting for potential benefits of applying wood ash to forested sites (e.g., increased timber yield or carbon sequestration) may make this disposal method more attractive. NRCan researchers are working to document and monetize these benefits and include them in calculations of net costs to 
determine whether the use of wood ash as a forest soil amendment could become more desirable in the future. Reductions in the cost and time required to obtain regulatory approval could also lower both the perceived and actual costs of wood ash application on Canadian forest soils.

\section{Examining wood ash applications as a tool for emulating natu- ral disturbance}

Increasingly, management practices that 'emulate natural disturbance' (END) are being promoted as a means of accommodating conflicting demands for ecological and economic goods and services from Canadian forests (Perera et al. 2004). Wildfire is the dominant stand-replacing disturbance across large regions of the country but the chemical effects of wildfire on soil properties are difficult to emulate (McRae et al. 2001). Both wildfires and applications of wood ash typically increase surface soil $\mathrm{pH}$ and base cation availability (Bodí et al. 2014, Reid and Watmough 2015) but there has been little work to directly compare the response of soil properties and processes to these two types of disturbance (Noyce et al. 2016). To this end, AshNet collaborators are conducting a formal meta-analysis to statistically compare changes in soil chemical properties following wildfire and wood ash applications. Furthermore, as part of the Island Lake Biomass Harvest Experiment in northeastern Ontario, changes in soil chemistry, soil biology, tree growth and forest ecology following applications of wood ash are being compared with those following a natural wildfire (Boisvert-Marsh et al. 2016).

\section{Monitoring the effect of ash applications on forested sites}

Research trials have been established by AshNet collaborators on forested sites in British Columbia, Saskatchewan, Manitoba, Ontario and Québec to examine the implications for tree growth, water quality and forest ecology of applying wood ash to forest soils. Research in Europe has demonstrated that co-applications of wood ash with N-rich fertilizers can be used to improve tree growth on sites where productivity is limited by N (Saarsalmi et al. 2014); thus, several Canadian studies are also investigating the possibility of coapplying wood ash with urea, N-P-S fertilizer, or N-rich municipal or pulp and paper mill biosolids. The results of these experiments will be used to assist policy makers and forest managers in developing best management practices specific to applications of wood ash on Canadian forest soils. Knowledge gaps will also be identified to facilitate the establishment of new strategically designed experiments. This work will be shared and synthesized via AshNet to help improve forest management practices and protect nutrient reserves on sites where woody biomass has been harvested to produce bioenergy.

\section{Conclusions}

There is growing interest in producing energy from forest biomass in Canada. Although concerns have been raised about the implications of intensive biomass removal for longterm forest productivity and biodiversity, management of the wood ash generated as a by-product of biomass combustion must also be considered. At present, much of the wood ash produced in Canada is landfilled. However, this ash could be applied to forest soils to replace the nutrients removed during timber and biomass harvesting, to improve tree growth and to counteract the effects of acid rain on soil and surface water $\mathrm{pH}$. AshNet is a network of scientists, foresters, policy makers and industry representatives who are working together to address barriers to the use of wood ash as a forest soil amendment in Canada. This work includes:

- Compiling information on the process required to obtain regulatory approval for using wood ash as a soil amendment in each Canadian province/territory;

- Gathering data on wood ash chemistry from a range of feedstocks and boiler types across the country;

- Examining practical methods of optimizing wood ash quality and applying wood ash on forested sites;

- Comparing the costs and benefits of applying ash on forest soils versus disposing of ash in landfills;

- Evaluating the utility of wood ash applications on forest soils as a means of emulating the effects of wildfire on soil chemical properties; and,

- Informing policy development by sharing the results of wood ash research trials established on forested sites in British Columbia, Saskatchewan, Manitoba, Ontario and Québec.

Progress on the work of AshNet and its collaborators will be continually updated at (http://cfs.nrcan.gc.ca/projects/ 140 (English); http://scf.rncan.gc.ca/projets/140?lang=fr_CA (French)).

\section{Acknowledgements}

Financial support for this project was provided by the Program of Energy Research and Development (PERD) of Natural Resources Canada through the project "Amelioration of biomass harvested sites with wood ash waste: Improving Canadian forest productivity and sustainability through an alternative approach to bioenergy waste management".

\section{References}

Bodí, M.B., D.A. Martin, V.N. Balfour, C. Santín, S.H. Doerr, P. Pereira, A. Cerdà and J. Mataix-Solera. 2014. Wildland fire ash: Production, composition and eco-hydro-geomorphic effects. EarthScience Reviews 130: 103-127. doi: 10.1016/j.earscirev.2013.12.007. Boisvert-Marsh, L., I. Aubin, R. Fleming, P. Hazlett, D. Morris, L. Venier, K. Webster and S. Wilson. 2016. The Island Lake Biomass Harvest Experiment: Early Results. Information Report GLC-X-16. Available from: http://cfs.nrcan.gc.ca/publications/download-pdf/ 37776 (English) or http://scf.rncan.gc.ca/publications/telechargerpdf/37776 (French) [accessed 7 February 2017]

Dymond, C.C., B.D. Titus, G. Stinson and W.A. Kurz. 2010. Future quantities and spatial distribution of harvesting residue and dead wood from natural disturbances in Canada. For. Ecol. Manage. 260: 181-192. doi: 10.1016/j.foreco.2010.04.015

Elliott, A. and T. Mahmood. 2006. Beneficial uses of pulp and paper power boiler ash residues. TAPPI Journal 5: 9-16.

Elliot, A. and T. Mahmood. 2015. Generation and management of solid residues by Canadian pulp and paper mills in 2013. Confidential report prepared for FPInnovations.

Forestry Commission. 2009. Guidance on site selection for brash removal. Available from: http://www.forestry.gov.uk/pdf/Brash_ residue_protocol.pdf/\$file/Brash_residue_protocol.pdf [accessed $2 \overline{2}$ July 2016]

Griffin, B. and J. Nyboer. 2016. Renewable Energy in Canada 2015. Canadian Industrial Energy End-use Data and Analysis Centre. Simon Fraser University, Burnaby, B.C. Available from: http://www2.cieedac.sfu.ca/media/publications/Renewable_Energy _Report_2016_-_Final.pdf [accessed 29 August 2016]. 
Hannam, K.D., C. Deschamps, M. Kwiaton, L. Venier and P.W. Hazlett. 2016. Regulations and guidelines for the use of wood ash as a soil amendment in Canadian forests. Information Report GLC-X17. Available from http://cfs.nrcan.gc.ca/pubwarehouse/pdfs/ 37781.pdfs(English) or http://cfs.nrcan.gc.ca/pubwarehouse/ pdfs/37782.pdf(French) [accessed 17 January 2017]

Hébert, M. and B. Breton. 2009. Recyclage agricole des cendres de bois au Québec - État de la situation, impacts et bonnes pratiques agro-environnementales. Agrosolutions 19: 18-33. Available from: http://www.irda.qc.ca/assets/documents/Publications/documents/ hebert-breton-2008_article_recyclage_agricole_cendres.pdf. [accessed 28 October 2016]

Hope, E.S., D.W. McKenney, D.J. Allen and J.H. Pedlar. In review. A cost analysis of bioenergy-generated ash disposal options in Canada. (submitted to the Canadian Journal of Forest Research, December 2016).

Huotari, N., E. Tillman-Sutela, M. Moilanen and R. Laiho. 2015. Recycling of ash - For the good of the environment? For. Ecol. Manage. 348: 226-240. doi: 10.1016/j.foreco.2015.03.008.

Karltun, E., A. Saarsalmi, M. Ingerslev, M. Mandre, S. Andersson, T. Gaitnieks, R. Ozolinčius and I. Varnagiryte-Kabasinskiene. 2008. Wood ash recycling - possibilities and risks. In: D. Röser, A. Asikainen, K. Raulund-Rasmussen and I. Stupak (eds.) Sustainable use of forest biomass for energy: A synthesis with focus on the Baltic and Nordic Region. pp. 79-108. Springer, Dordrecht, The Netherlands.

Lattimore, B., C.T. Smith, B.D. Titus, I. Stupak and G. Egnell. 2009. Environmental factors in woodfuel production: Opportunities, risks, and criteria and indicators for sustainable practices. Biomass Bioenergy 33: 1321-1342. doi: 10.1016/j.biombioe.2009.06.005 McRae, D.J., L.C. Duchesne, B. Freedman, T.J. Lynham and S. Woodley. 2001. Comparisons between wildfire and forest harvesting and their implications in forest management. Environ. Rev. 9: 223-260. doi: 10.1139/a01-010.

National Energy Board of Canada. 2016. Canada's renewable power landscape: Energy market analysis 2016. Available from: https://www.neb-one.gc.ca/nrg/sttstc/lctrct/rprt/2016cndrnwblpwr/ 2016cndrnwblpwr-eng.pdf [accessed 28 October 2016].

Nishio, G. 2016. Forest biomass ash production in British Columbia. Confidential report prepared for FPInnovations.

Nishio, G. and T. Ersson. 2016a. Ash and biosolids spreading trial. FPIPRODUCT-173-657. Available from: https://fpinnovations.ca/ Extranet/Pages/AssetDetails.aspx?item=/Extranet/Assets/Research ReportsFO/TR2016N28.pdf\#.V79192U9X7Y [accessed 29 August 2016].
Nishio, G. and T. Ersson. 2016b. Spreading wood ash on forest land in Canada: An introduction. Technical Report no. 31.

Noyce, G.L., R. Fulthorpe, A. Gorgolewski, P. Hazlett, H. Tran and N. Basiliko. 2016. Soil microbial responses to wood ash addition and forest fire in managed Ontario forests. Appl. Soil Ecol. 107: 368-380. doi: 10.1016/j.apsoil.2016.07.006

Ontario Ministry of Natural Resources. 2008. Forest biofibre allocation and use. For. Manag. Br., Toronto, ON. For. Manag. Direct. FOR 0302 01. Available from: https://dr6j45jk9xcmk.cloudfront.net/documents/3099/stdprod-099834.pdf [accessed 16 October 2016].

Paré, D., E. Thiffault, G. Cyr and I. Guidon. 2016. Quantifying forest biomass mobilisation potential in the boreal and temperate biomes. In: E. Thiffault, G. Berndes, M. Junginger, J.N. Saddler and C.T. Smith (eds.) Mobilisation of forest bioenergy in the boreal and temperate biomes: Challenges, opportunities and case study. pp. 35-50. Elsevier, Amsterdam, The Netherlands.

Perera, A.H., L.J. Buse and M.G. Weber (eds.). 2004. Emulating Natural Forest Landscape Disturbances: Concepts and Applications. Columbia University Press, NY, p. 315 p.

Pitman, R.A. 2006. Wood ash use in forestry - a review of the environmental impacts. Forestry 79: 563-588. doi: 10.1093/forestry/ cpl041

Reid, C. and S.A. Watmough. 2015. Evaluating the effects of liming and wood-ash treatment on forest ecosystems through systematic meta-analysis. Can. J. For. Res. 44: 867-885. doi: 10.1139/cjfr-20130488

Roach, J. and S.M. Berch. 2014. A compilation of forest biomass harvesting and related policy in Canada. Prov. B.C., Victoria, B.C. Tech. Rep. 081. Available from: https://www.for.gov.bc.ca/hfd/ pubs/docs/tr/TR081.pdf [accessed 16 August 2016].

Saarsalmi, A., A. Smolander, M. Moilanen and M. Kukkola. 2014. Wood ash in boreal, low-productive pine stands on upland and peatland sites: Long-term effects on stand growth and soil properties. For. Ecol. Manage. 327: 86-95. doi: 10.1016/j.foreco.2014.04.031.

Thiffault, E., K.D. Hannam, D. Paré, B.D. Titus, P.W. Hazlett, D.G. Maynard and S. Brais. 2011. Effects of forest biomass harvesting on soil productivity in boreal and temperate forests - A review. Environ. Rev. 19: 278-319. doi: 10.1139/a11-009. 